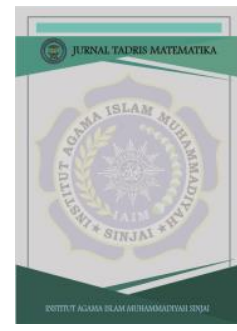

\title{
ANALISIS KESALAHAN SISWA DALAM MEMECAHKAN MASALAH PISA DITINJAU DARI GENDER
}

\author{
Nurjannah $^{1}$, Mirna $^{2}$, Nurlili $^{3}$, Andi Auliya Ismunandar ${ }^{4}$ \\ ${ }^{I}$ Institut Agama Islam Muhammadiyah Sinjai \\ ${ }^{2}$ Institut Agama Islam Muhammadiyah Sinjai \\ , 3 Institut Agama Islam Muhammadiyah Sinjai \\ E-mail: nurjannah310807@gmail.com, Tlp.085255981301
}

\begin{abstract}
Abstrak
Penelitian ini merupakan penelitian kualitatif dengan pendekatan deskriptif yang bertujuan mendeskripsikan hasil analisis kesalahan siswa berdasarkan tahapan Polya dalam memecahkan masalah PISA ditinjau dari gender. Penelitian ini dilaksanakan di SMPN 20 Sinjai. Pengumpulan data dilakukan dengan pemberian tugas pemecahan masalah matematika berupa soal PISA dan wawancara. Untuk menguji kredibiltas data dilakukan dengan triangulasi waktu. Pada tahap memahami masalah dan membuat rencana penyelesaian, subjek perempuan tidak melakukan kesalahan. Pada tahap melaksanakan rencana, hasil perhitungan yang diperoleh subjek salah karena subjek tidak mampu memahami dan menghubungkan konsep yang sesuai dengan masalah yang sedang dihadapi. Pada tahap memeriksa kembali, subjek menguji dan memeriksa langkah-langkah dan hasil perhitungan yang dilakukan berulangkali untuk memastikan bahwa hasil perhitungan sudah benar meskipun kenyataannya jawabannya masih salah karena memang konsep yang digunakan untuk menyelesaikan soal PISA tersebut salah. Pada tahap membuat rencana penyelesaian, subjek laki-laki melakukan kesalahan yakni membuat perencanaan pemecahan masalah tanpa menggunakan konsep yang benar. Pada tahap melaksanakan rencana, subjek melaksanakan strategi yang dipilih. Pada tahap memeriksa kembali, subjek melakukan pengecekan dengan menguji dan memeriksa kembali langkah demi langkah strategi pemecahan masalah yang digunakan dan semua sudah sesuai. Namun karena strategi yang dipilih hanya tebakan, maka subjek tidak mengetahui bahwa jawaban yang diperoleh salah.
\end{abstract}

Kata Kunci: Pemecahan Masalah, Soal PISA, Gender

\begin{abstract}
This research was a qualitative research with a descriptive approach which aims to describe the results of student error analysis based on Polya's stages in solving PISA problems in terms of gender. This research was conducted at SMPN 20 Sinjai. Data collection was carried out by giving math problem solving tasks in the form of PISA questions and interviews. Time triangulation was used to test the credibility of the data. At the stage of understanding the problem and making a resolution plan, the female subject did not make a mistake. At the stage of implementing the plan, the calculation results obtained by the subject are wrong because the subject is not able to understand and relate the concept that is in accordance with the problem at hand. At the rechecking stage, the subject tests and checks the steps and results of calculations that are carried out repeatedly to ensure that the calculation results are correct even though in fact the answer is still wrong because the concept used to solve the PISA problem is wrong. At the stage of making a completion plan, the male subject made a mistake, namely making a problem-solving plan without using the correct concept. At the stage of executing the plan, the subject carries out the chosen strategy. At the rechecking stage, the subject checks by testing and re-checking step by step the problem-solving strategies used and everything is
\end{abstract}


appropriate. However, because the strategy chosen was only a guess, the subject did not know that the answer was wrong.

Keywords: Problem-solving, PISA's problem, Gender.

\section{Pendahuluan}

Pendidikan yang bermutu pada dasarnya menghasilkan sumber daya manusia yang bermutu pula. Sumber daya manusia yang bermutu tidak tercipta dengan sendirinya, tetapi melalui pendidikan yang sesuai dengan perkembangan anak. Mereka yang mendapat layanan pendidikan itu kemudian menjadi manusia dewasa yang memiliki kualifikasi ahli, terampil, kreatif, inovatif, serta memiliki sikap dan perilaku yang positif. Mutu manusia Indonesia yang akan datang harus lebih baik dari sekarang, karena kemajuan suatu bangsa ditandai dengan sumber daya manusianya yang berkualitas (Danial, Nurjannah, Mirna 2019).

Hal yang paling penting dalam pembelajaran yang harus diperhatikan adalah proses, bukan semata-mata hasil akhir. Olehnya itu, proses pembelajaran tidak dapat dianggap enteng karena didalamnya terdapat nilai yang sangat penting yang akan mencerminkan kemampuan siswa. Hal ini berlaku pula pada proses pemecahan masalah. Karena pemecahan masalah tidak lepas dari prosesnya yang memerlukan pemikiran yang ekstra (Nurgiyantoro, 2010).

Dalam pembelajaran matematika, pertanyaan atau masalah yang dihadapkan kepada siswa biasanya dalam bentuk soal cerita (Hidayah, 2016) (Nurjannah, 2019). Sebagian besar ahli Pendidikan Matematika menyatakan bahwa masalah merupakan pertanyaan yang harus dijawab atau direspon, tetapi mereka juga menyatakan bahwa tidak semua pertanyaan otomatis akan menjadi masalah (Nurjannah, 2020). Suatu pertanyaan akan menjadi masalah hanya jika pertanyaan itu menunjukkan adanya suatu tantangan (challenge) yang tidak dapat dipecahkan dengan suatu prosedur rutin (routine procedure) yang sudah diketahui oleh pemecah masalah (Dhurori, A \& Markaban, 2010.

Tripathi (2011) mengemukakan bahwa pemecahan masalah merupakan proses di mana individu menggunakan pengetahuan, keterampilan, dan pemahaman yang telah diperoleh untuk nenyelesaian masalah pada situasi yang tidak dikenalnya. Siswa dituntut untuk memahami keseluruhan masalah yang terjadi kemudian barulah siswa dapat menyusun gambaran masalah tersebut (Culaste, 2012). Setelah siswa membuat gambaran dari masalah yang terjadi, maka siswa akan menjelaskan serta mendiskusikan gambaran tadi sesuai dengan pemahaman masing-masing kemudian menyelesaikan masalah tersebut dengan ilmu atau pengetahuan yang mereka miliki yang berkaitan dengan masalah yang dihadapi. Polya (2014) membagi langkah pemecahan masalah menjadi 4 tahap, yaitu: 1) memahami masalah, 2) membuat rencana, 3) melaksanakan rencana, dan 4) memeriksa kembali.

Masalah yang berskala internasional yang banyak menjadi perhatian khususnya pada mata pelajaran matematika adalah PISA. PISA (Program for International Student Assessment) dilaksanakan secara regular sekali dalam tiga tahun sejak tahun 2000 untuk mengetahui literasi siswa usia 15 tahun dalam matematika, sains, dan membaca. Fokus dari PISA adalah literasi yang menekankan pada keterampilan dan kompetensi siswa yang diperoleh dari sekolah dan dapat digunakan dalam kehidupan sehari-hari dan dalam berbagai situasi (OECD dalam Johar, 2012) (OECD, dalam Anwar, 2018).

Menurut Wilken (Hawa, 2014), tujuan umum dari PISA adalah untuk menilai sejauh mana siswa berusia 15 tahun di negara OECD (dan negara lainnya) telah memperoleh kemahiran yang tepat dalam membaca, matematika dan ilmu pengetahuan untuk membuat kontribusi yang signifikan terhadap masyarakat mereka. Selain itu, tujuan PISA adalah untuk mengukur prestasi literasi membaca, matematika, dan sains siswa sekolah berusia 15 tahun di negara-negara peserta bagi Indonesia (Kemendikbud, 2016). Oleh karena itu, hasil studi di harapkan dapat digunakan sebagai masukkan dalam perumusan kabijakan untuk peningkatan mutu pendidikan.

Keterlibatan Indonesia dalam Program for International Student Assessment (PISA) adalah upaya melihat sejauh mana program pendidikan di negara kita berkembang dibanding negara-negara lain di dunia. Hal ini menjadi sangat penting dilihat dari kepentingan anak-anak kita di masa depan 


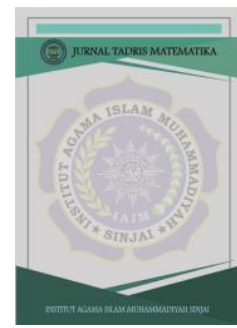

JTMT

Jurnal Tadris Matematika

Vol 1 No 22020

ISSN (print) : 2745-956X

ISSN (online) : 2745-9551

Homepage : http://journal.iaimsinjai.ac.id/index.php/Jtm

yang akan datang sehingga mampu bersaing dengan negara-negara lain dalam era globalisasi. (Rahmawati, Annajmi, Hardianto).

Jika dipandang pada sudut pandang gender, maka siswa laki-laki dan perempuan mempunyai kelebihan dan kekurangan tersendiri dalam mengerjakan soal matematika. Krutetskii (Anwar, 2018) berpendapat laki-laki unggul dalam penalaran logis sedangkan perempuan unggul dalam ketetapan, ketelitian, dan keseksamaan dalam berfikir. Pendapat lain mengemukakan bahwa kemampuan mengingat anak perempuan cenderung lebih baik dibandingkan anak laki-laki (Anwar, 2018).

Dari uraian di atas dapat disimpulkan bahwa gender berpengaruh terhadap kemampuan seseorang dalam belajar matematika, sehingga kemungkinan terdapat perbedaan dalam memecahkan soal matematika khususnya soal-soal tingkat tinggi seperti soal PISA. Oleh karena itu, dalam penelitian ini peneliti juga tertarik mengungkap bagaimana kesalahan siswa dalam menyelesaikan soal berbasis PISA ditinjau dari perbedaan gender. Soal PISA yang dimaksudkan di dalam penelitian ini adalah soal PISA berupa literasi matematika pada topik Statistika yang jarang diteliti karena kebanyakan peneliti hanya berfokus pada konten uncertainty dan quantity.

\section{Metode}

Jenis penelitian ini adalah penelitian deskriptif dengan pendekatan kualitatif yang bertujuan untuk mendeskripsikan kesalahan subjek saat memecahkan masalah matematika. Subjek penelitian adalah siswa kelas VIII berjenis kelamin laki-laki dan perempuan yang berkemampuan matematika relatif sama dan berkemampuan komunikasi baik. Kelas VIII dipilih karena materi yang digunakan pada Tugas Pemecahan Masalah PISA dimana subjek berada pada tahap operasional konkret ke tahap formal. Metode pengumpulan data yang digunakan dalam penelitian ini ada dua, yakni metode tugas dan wawancara semi terstruktur. Siswa penelitian diberikan Tugas Pemecahan Masalah Matematika (TPMM) yang merupakan soal PISA kemudian dilakukan wawancara yang berkaitan dengan tugas yang telah diselesaikan. Adapun Teknik analisis data dilakukan dengan reduksi, penyajian data dan penarikan kesimpulan. Berikut ditampilkan soal PISA yang digunakan pada penelitian ini.

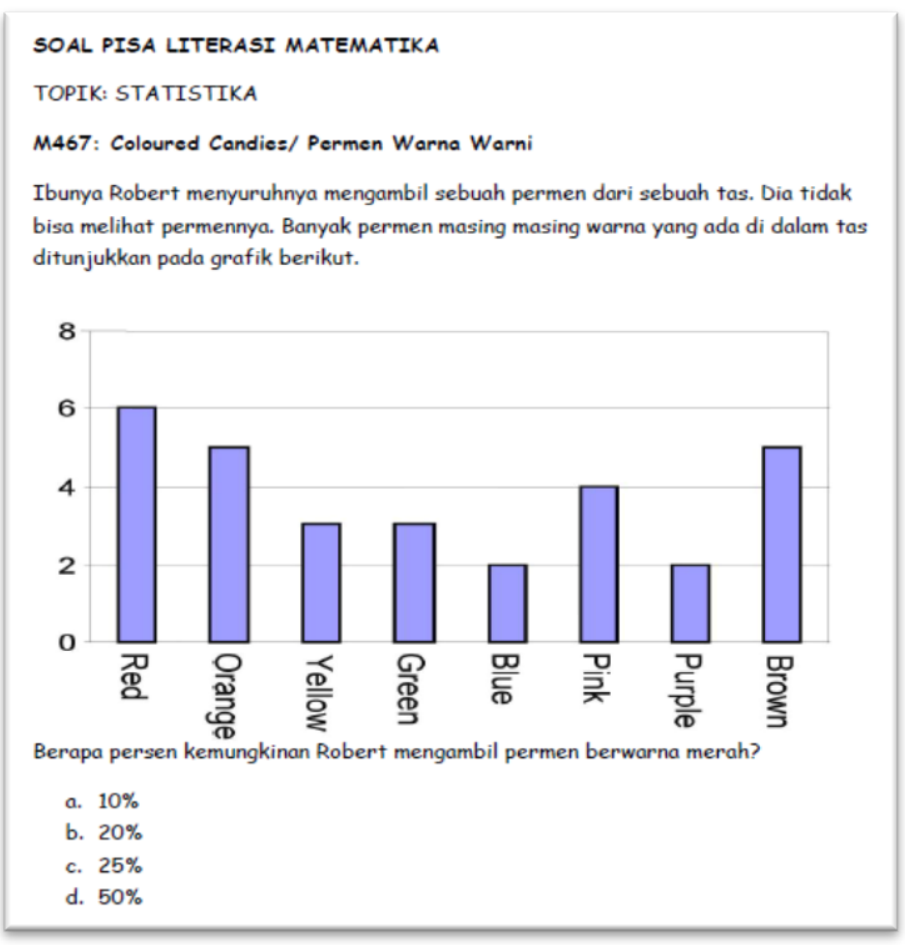

Gambar 1. Soal PISA 


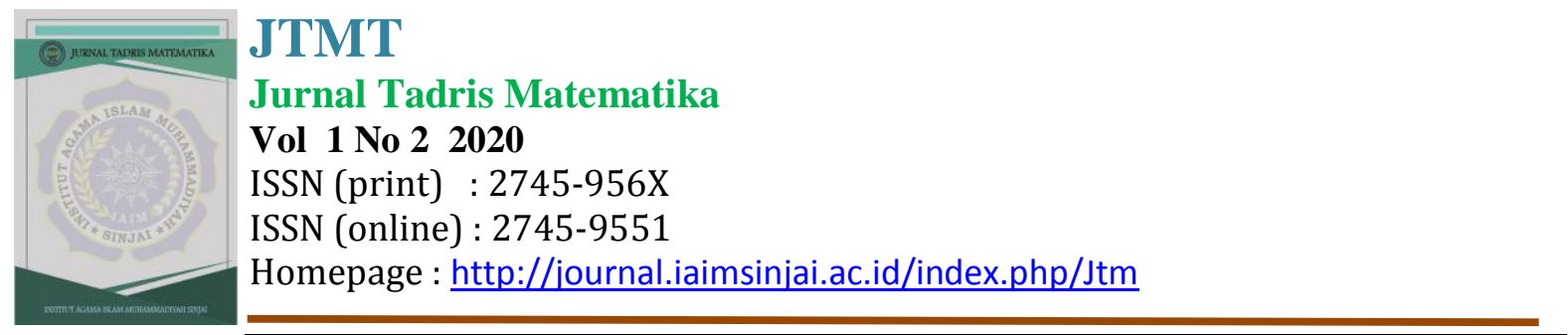

3. Hasil dan Pembahasan

a. Analisis Kesalahan Siswa Perempuan dalam memecahkan soal PISA Tahapan Polya

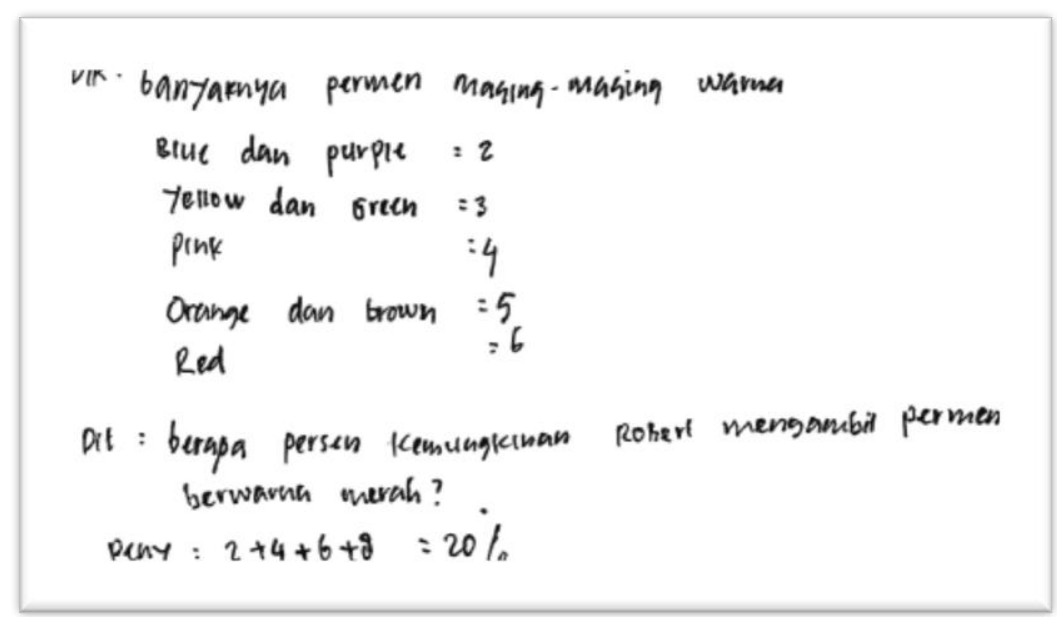

Gambar 2. Hasil Jawaban Siswa Perempuan

Pada tahap memahami masalah, siswa perempuan mengidentifikasi masalah dengan cara menentukan kata kunci dari masalah yang dihadapi akan tetapi subjek tidak dapat memahami secara utuh maksud dari soal karena siswa tidak mengetahui konsep apa yang berhubungan dengan soal tersebut.

Pada tahap membuat rencana penyelesaian, Siswa memilih ide/cara yang dianggap tepat dalam pemecahan masalah. Kemudian melakukan pengujian. Karena siswa tidak dapat langsung melaksanakan cara kedua, siswa lalu memikirkan dan membayangkan cara-cara selanjutnya untuk memecahkan masalah PISA tersebut.

Pada tahap melaksanakan rencana, Siswa melaksanakan strategi yang dipilih dalam soal akan tetapi konsep yang digunakan untuk menyelesaikan masalah tersebut salah hal ini terjadi karena siswa tidak mampu memahami dan menghubungkan konsep yang sesuai dengan masalah yang sedang dihadapi sehingga hasil perhitungannya salah. Pada TPMM 1, konsep yang seharusnya digunakan adalah konsep peluang dengan menghitung jumlah keseluruhan warna kemundian mencari persentase permen yang berwarna merah. Akan tetapi, subjek hanya langsung menjumlahkan angka-angka yang terdapat pada grafik sehingga hasilnya salah. Sedangkan pada TPMM 2, konsep yang seharusnya digunakan untuk menyelesaikan soal adalah konsep rata-rata. Akan tetapi, subjek hanya langsung menentukan jawaban dengan melihat-lihat angka pada soal tanpa menggunakan konsep yang benar.

Pada tahap memeriksa kembali, siswa menguji dan memeriksa langkah-langkah dan hasil perhitungan yang siswa lakukan berulangkali untuk memastikan bahwa hasil perhitungan sudah benar meskipun kenyataannya jawabannya masih salah karena memang konsep yang digunakan untuk menyelesaikan soal PISA tersebut salah. 


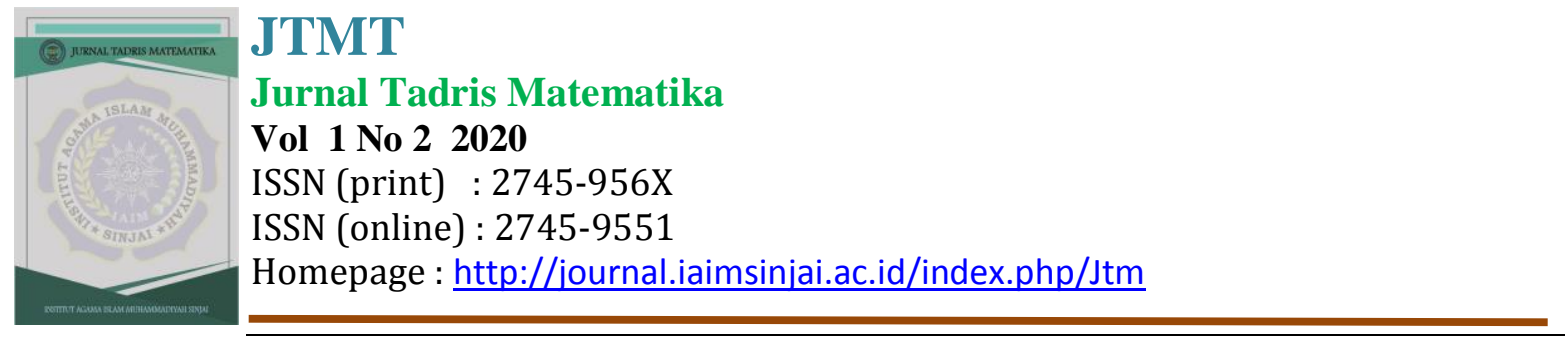

b. Analisis Kesalahan Siswa dalam memecahkan soal PISA Tahapan Polya Siswa Laki-laki

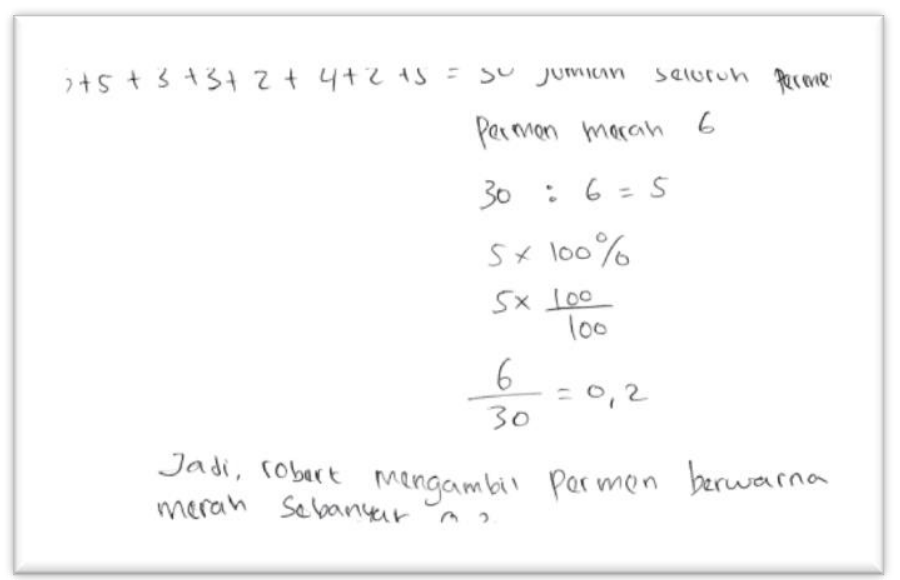

\section{Gambar 3. Hasil Jawaban Siswa Laki-laki}

Pada tahap memahami masalah, subjek memahami masalah yang diberikan pada soal TPMM dengan mengidentifikasi masalah dengan cara menentukan kata kunci dari masalah yang dihadapi setelah membaca soal. Kemudian mengumpulkan informasi/fakta matematika yang terkait dengan soal yang nantinya akan digunakan untuk memecahkan masalah tersebut. Setelah itu, mengaitkan informasi/fakta matematika dengan soal.

Pada tahap membuat rencana penyelesaian, subjek memilih ide atau cara yang dianggap tepat kemudian menjelaskan konsep ide pemecahan masalah. Lalu, subjek merencanakan proses penyelesaian dengan membangun dan mengembangkan ide kunci pemecahan masalah dengan membuat penjelasan dan penalaran yang logis berdasarkan aturan atau konsep matematika yang berhubungan dengan ide yang subjek temukan.

Pada tahap melaksanakan rencana, untuk TPMM 1 subjek melaksanakan strategi menggunakan informasi yang terdapat pada soal. Meskipun dengan strategi tersebut memakan waktu yang cukup lama. Subjek hanya melakukan tebak-tebakan mengenai cara yang digunakan tanpa mengetahui konsep sebenarnya. Alasan lain dijelaskan karena tidak ada lagi cara yang ditemukan untuk memecahkan masalah, sedangkan jawaban sementara terdapat pada pilihan jawaban yang tersedia. Sedangkan untuk TPMM 2 melaksanakan strategi menggunakan informasi yang terdapat pada soal dan menjelaskan alasan menggunakan strategi yang dipilih.

Pada tahap memeriksa kembali, subjek melakukan pengecekan dengan menguji dan memeriksa kembali langkah demi langkah strategi pemecahan masalah yang digunakan dan semua sudah sesuai. Selanjutnya, subjek memeriksa kembali hasil perhitungan yang diperoleh. Lalu subjek memastikan kembali hasil perhitungan dengan mengoperasikannya sesuai rumus.

\section{c. Persamaan dan Perbedaan Kesalahan Siswa dalam Memecahkan Soal PISA}

Berdasarkan penelitian, terdapat kesamaan antara siswa perempuan dan laki-laki pada tahap memahami masalah yakni membaca soal secara seksama. Selain itu, terdapat kesamaan antara siswa perempuan dan laki-laki pada tahap memahami masalah yakni menentukan informasi yang relevan dengan masalah yang dihadapi yaitu siswa menentukan kata kunci serta informasi yang diketahui dari soal dan menggunakan materi yang relevan untuk memecahkan masalah tersebut.

Pada tahap membuat rencana, siswa laki-laki dan perempuan kemudian melakukan pengujian. Karena siswa tidak langsung memikirkan dan membayangkan cara-cara selanjutnya untuk memecahkan masalah PISA tersebut. Pada tahap melaksanakan rencana, siswa melaksanakan strategi yang dipilih dalam pemecahan masalah. Ketika mengalami kesulitan siswa berhenti memikirkan masalah. Pada tahap memeriksa kembali, siswa menguji dan memeriksa langkah-langkah dan hasil perhitungan yang siswa lakukan berulangkali untuk memastikan bahwa hasil perhitungan sudah benar. 


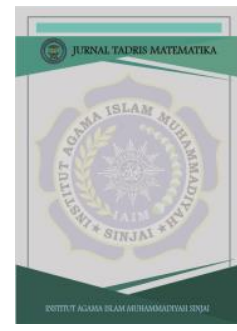

JTMT

Jurnal Tadris Matematika

Vol 1 No 22020

ISSN (print) : 2745-956X

ISSN (online) : 2745-9551

Homepage : http://journal.iaimsinjai.ac.id/index.php/Jtm

Adapun perbedaan kesalahan siswa dalam memecahkan masalah PISA adalah sebagai berikut. Pada tahap melaksanakan rencana, siswa perempuan melaksanakan strategi yang dipilih dengan berusaha mencari jawaban. Pada saat mengalami kesulitan siswa melamun dan menggaruk-garuk kepala.Siswa kemudian menggunakan informasi yang terdapat pada soal dengan mengembangkan ide kunci pemecahan masalah PISA dengan membuat penjelasan dan penalaran yang logis berdasarkan konsep matematika dalam pemecahan masalah PISA tersebut. Sedangkan siswa laki-laki, Pada tahap melaksanakan rencana,siswa melaksanakan strategi yang dipilih dalam pemecahan masalah,ketika mengalami kesulitan siswa berhenti memikirkan masalah yang dihadapi dan memikirkan hal yang tidak ada hubungannya dengan soal.Siswa sangat kesulitan dalam mengerjakan soal PISA tersebut.

Berdasarkan jawaban masing-masing siswa, perbedaannya terletak pada jumlah cara yang berhasil dikerjakan siswa. Siswa perempuan terlihat sangat susah dalam menyelesaikan masalah PISA tersebut sehingga siswa memecahkan masalah dengan menggunakan strategi penjumlahan.Melaksanakan strategi dan menggunakan informasi yang terdapat pada soal. Dalam hal ini, subjek menggunakan strategi penjumlahan yaitu menjumlahkan semua jenis warna permen dalam grafik tersebut.Sedangkan pada soal kedua, Melaksanakan rencana pemecahan masalah dengan memperhatikan soal denganseksama tetapi tidak dapat langsung melaksanakan cara pemecahan masalah kedua, maka subjek memikirkan dan membayangkan cara-cara selanjutnya untuk memecahkan masalah. Sedangkan pada siswa laki-laki terlihat kesulitan dalam memecahkan masalah tersebut. Sehingga siswa memecahkan masalah dengan menggunakan strategi. Yaitu melaksanakan strategi dan menggunakan informasi yang terdapat pada soal. Dalam hal ini,subjek menggunakan strategi pembagian yaitu membagi jumlah semua jenis warna permen dalam grafik dengan permen berwarna merah. Pada soal kedua, siswa laki-laki melaksanakan strategi dan menggunakan informasi yang terdapat pada soal.

\section{Simpulan}

Terdapat perbedaan mendasar letak kesalahan antara siswa perempuan dan laki-laki dalam memecahkan soal PISA. Berikut letak perbedaan kesalahan siswa perempuan dan laki-laki. Analisis kesalahan siswa perempuan dalam memecahkan soal PISA yaitu pada tahap memahami masalah dan membuat rencana penyelesaian, subjek tidak melakukan kesalahan karena siswa mampu mengidentifikasi masalah dengan cara menentukan kata kunci dari masalah yang dihadapi akan tetapi subjek tidak dapat memahami secara utuh maksud dari soal karena siswa tidak mengetahui konsep apa yang berhubungan dengan soal tersebut. Pada tahap melaksanakan rencana, hasil perhitungan yang diperoleh subjek salah. Hal ini terjadi karena siswa tidak mampu memahami dan menghubungkan konsep yang sesuai dengan masalah yang sedang dihadapi sehingga hasil perhitungannya salah. Hal ini berdampak pada tahap memeriksa kembali, subjek menguji dan memeriksa langkah-langkah dan hasil perhitungan yang dilakukan berulangkali untuk memastikan bahwa hasil perhitungan sudah benar meskipun kenyataannya jawabannya masih salah karena memang konsep yang digunakan untuk menyelesaikan soal PISA tersebut salah.

Analisis kesalahan siswa laki-laki dalam memecahkan soal PISA yaitu pada tahap memahami masalah dan membuat rencana penyelesaian, subjek tidak melakukan kesalahan karena mengidentifikasi masalah dengan cara menentukan kata kunci dari masalah yang dihadapi setelah membaca soal. Kemudian mengumpulkan informasi/fakta matematika yang terkait dengan soal yang nantinya akan digunakan untuk memecahkan masalah tersebut. Pada tahap membuat rencana penyelesaian, subjek melakukan kesalahan yakni dengan membuat perencanaan pemecahan masalah tanpa menggunakan konsep yang benar. Atau dengan kata lain, subjek hanya menerka-nerka konsep apa yang sesuai untuk menyelesaikan masalah tersebut. Pada tahap melaksanakan rencana, subjek melaksanakan strategi yang dipilih. Akan tetapi, karena rencana yang dipilih tidak didasari dengan konsep yang kuat maka hasil pemecahan masalah yang diperoleh salah. Pada tahap memeriksa kembali, subjek elakukan pengecekan dengan menguji dan memeriksa kembali langkah demi langkah 


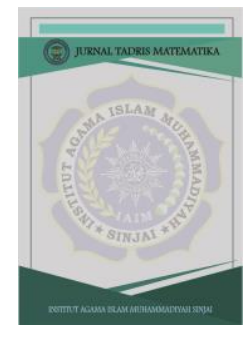

JTMT

Jurnal Tadris Matematika

Vol 1 No 22020

ISSN (print) : 2745-956X

ISSN (online) : 2745-9551

Homepage : http://journal.iaimsinjai.ac.id/index.php/Jtm

strategi pemecahan masalah yang digunakan dan semua sudah sesuai. Namun karena strategi yang dipilih hanya tebakan, maka subjek tidak mengetahui bahwa jawaban yang diperoleh salah.

\section{Daftar Pustaka}

Anwar, M.K. (2018). Analisis Kemampuan dan Kesalahan dalam Menyelesaikan Soal Cerita Matematika Berorientasi PISA ditinjau dari Gender Pada Siswa Kelas VII SMP Muhammadiyah 2 Surakarta. E-prints Universitas Muhammadiyah Surakarta. Retrieved from http://eprints.ums.ac.id/69867/11/NASPUB\%20fix.pdf.

Culaste, I. C. (2011). Cognitive Skills of Mathematical Problem Solving of Grade 6 Children. International Journal of Innovative Interdisciplinary Research, 2(5), 117-130. Retrieved from https://silo.tips/download/cognitive-skills-of-mathematical-problem-solving-of-grade6-children.

Danial, D, Nurjannah, N, Mirna, M. (2019). Evaluasi Pelaksanaan Pembelajaran Program Studi Tadris Matematika di Institut Agama Islam Muhammadiyah Sinjai. Jurnal Matematika dan Pembelajaran, $\quad 7(1), \quad 65-80 . \quad$ Retrieved from https://jurnal.iainambon.ac.id/index.php/INT/article/view/1046.

Dhurori, A \& Markaban. (2010). Pembelajaran Kemampuan Pemecahan Masalah dalam Kajian Aljabar Di SMP (Modul Matematika SMP Program BERMUTU). Yogyakarta: P4TK Matematika. Retrieved from https://core.ac.uk/download/pdf/232217462.pdf.

Rahmawati, E, Annajmi, Hardianto. (2016). Analisis Kemampuan Matematis Siswa SMP dalam Menyelesaikan Soal Matematika Bertipe PISA. Jurnal Pendidikan Matematika, 1-5. Retrieved from http://e-journal.upp.ac.id/index.php/mtkfkip/article/view/930.

Hawa, A. M. (2014). Analisis Kemampuan Siswa Menyelesaikan Soal Matematika Siswa Bertipe PISA. Seminar Nasional Evalusi Pendidikan. PPs UNS.Semarang. Retrieved from https://conf.unnes.ac.id/index.php/snep/II/paper/viewFile/269/163.

Hidayah, S. (2016). Analisis Kesalahan Siswa Dalam Menyelesaikan Soal Cerita SPLDV Berdasarkan Langkah Penyelesaian Polya. Prosiding Seminar Nasional Pendidikan Matematika Universitas Kanjuruhan Malang, 1, 182-190. Retrieved from https://conf.unnes.ac.id/index.php/snep/II/paper/viewFile/269/163.

Kemendikbud. (2016). Peringkat dan Capaian PISA Indonesia Mengalami Peningkatan. [Online] https://www.kemdikbud.go.id/main/blog/2016/12/peringkat-dan-capaian-PISA-indonesiamengalami-peningkatan.

Nurgiyantoro, B. (2010). Penilaian Pembelajaran Sastra Berbasis Kompetensi. Yogyakarta: BPFE.

Nurjannah, N. (2019). Eksplorasi Metakognisi Terhadap Pemecahan Masalah Matematika ditinjau dari Gaya Belajar Siswa. AULADUNA: Jurnal Pendidikan Dasar Islam, 6(1), 78-89. Retrieved from http://journal.uin-alauddin.ac.id/index.php/auladuna/article/view/78-89.

Nurjannah, N. (2020). Proses Berpikir Kreatif Siswa SMP dalam Memecahkan Masalah Matematika ditinjau dari Adversity Quotient. Jurnal Tadris Matematika, 1(1), 7-13. Reyrieved from http://journal.iaimsinjai.ac.id/index.php/Jtm/article/view/391.

Nurjannah, N., Nurhalizah, N., Irmawati, E., \& Ismunandar, A. A. (2020). Pembelajaran Matematika Berbasis Etnomatematika di Taman Purbakala Batu Pake Gojeng Kabupaten Sinjai. MEGA: Jurnal Pendidikan Matematika, 1(2), 62-74. Retrieved from https://ejournal.unmuhkupang.ac.id/index.php/mega/article/view/242 


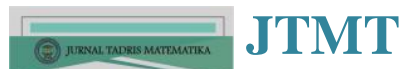

Jurnal Tadris Matematika

Vol 1 No 22020

ISSN (print) : 2745-956X

ISSN (online) : 2745-9551

Homepage : $\underline{\text { http://journal.iaimsinjai.ac.id/index.php/Jtm }}$

Polya, G. (2014). How to solve it: A New Aspect of Mathematical Method. Retrieved from https://press.princeton.edu/titles/669.html.

Johar, R. (2012). Domain Soal PISA untuk Literasi Matematika. Jurnal Peluang, Volume 1 No. 1, 30 41. Retrieved from http://jurnal.unsyiah.ac.id/peluang/article/view/1296.

Tripathi, P. (2011). Problem Solving in Mathematics: A Tool for Cognitive Development. Journal of Mathematics Education Trends and Research, 3, 14-29. Retrieved from http://cvs.gnowledge.org/episteme3/pro_pdfs/27-tripathi.pdf. 